\title{
Perceptions of Students and Teachers Regarding Blended Learning Use in the Elementary Schools
}

\author{
Sabina Ndiung ${ }^{1}$, Eliterius Sennen ${ }^{2}$, Yuliana Wahyu $^{3}$, Arnoldus Helmon ${ }^{4}$, Mariana Jediut ${ }^{5}$ \\ Universitas Katolik Indonesia Santu Paulus Ruteng, Indonesia ${ }^{1234}$ \\ \{punyaku79@gmail.com\}
}

\begin{abstract}
The Covid-19 pandemic has altered people's lives in all sectors, including the educational field. This idea resulted in establishing the learning from the home policy as an alternative to academic services for students. This study aims to describe the perceptions of students and teachers towards the implementation of mathematics learning using the blended learning method in elementary schools in the Manggarai regency. This type of research was survey research with the number of samples in this study were 42 elementary school students and 42 elementary school teachers. Based on the instrument validity test results, it was found that both the student's perception instrument and the teacher's perception were all declared valid, with the reliability coefficients being 0.84 and 0.81 , respectively, in the high category. The data analysis technique used quantitative descriptive techniques by analyzing respondents' answers to the instrument items on three dimensions. Based on the results of this study, it can be concluded that the implementation of blended mathematics learning for students in Manggarai regency has not done well. This happened because not all students had Android phones and laptops; unstable internet connection, some several student residence areas lacked an internet connection, limited internet quota, teachers were not accustomed to controlling student attendance in online learning or using google forms applications, teachers were not accustomed to giving assessments using certain applications, both teachers and students had not accustomed to using virtual faceto-face learning using video conferencing, which hinders the learning process during the Covid-19 pandemic.
\end{abstract}

Keywords: blended learning, covid-19 pandemic, teacher and student perceptions

\section{Introduction}

The Covid-19 pandemic has had an impact on the global community's way of life. In order to prevent the spread of the Corona Virus, people are encouraged and even forced to stay at home. Teaching-learning processes and various other types of work are recommended to be done from home. Almost every country urges their citizens not to move outside the home if there is no urgent need. One sector resulting from the Covid-19 pandemic is the education sector, which affects education services to avoid physical contact and suppress the rate of case development. This is clearly stated in the policy of the Minister of Education through circular letter Number 4 of 2020, which stated that learning from home through distance learning is carried out to provide meaningful learning experiences for students without being burdened, completing all curriculum achievements for grade promotion and graduation [1].

The learning system in the network (online) is a learning system without face-to-face directly between teachers and students but is carried out online using the internet network. 
Teachers must ensure that teaching and learning activities can be done, even though students are at home. The solution is that teachers must design learning media as innovations by utilizing online media [2]. Besides that, online learning is still considered a breakthrough or a new paradigm in teaching and learning activities, wherein the process of teaching and learning activities is because there is no need to attend classrooms among students and teachers. They only rely on an internet connection to carry out the learning activities, and the process can be carried out from faraway places [3].

Because of the convenience and practicality of the virtual system or online learning, it is not surprising that many schools use online learning. Thus, online learning can be done from wherever students and teachers are. However, the question is whether activity and learning psychology in online learning have the same situation or at least close to activities and learning psychology in face-to-face learning. Several problems are encountered in online learning, such as teaching materials, learning interactions, learning environments, ICT infrastructure availability, and stable internet connection [4], [5].

As an abstract science that is a scourge for most students, mathematics is presented through online and offline methods, which are only presented in the form of a collection of tasks that make it very difficult for them to understand. This idea is supported by sharing data with teachers and unstructured interviews with elementary school students. Most students convey the problem of their lack of understanding of the material presented, and some students do assignments without having a quite understanding. Meanwhile, from the teachers' view, they find it difficult to coordinate with students individually and only a small number of students understand the ICT.

In addition, teachers find it difficult to measure students' level of understanding due to assignments done at home, sometimes carried out by parents or peers who have more abilities. Online learning is a learning approach, which in its implementation is not done face-to-face in class but through information communication technology by using internet facilities. One form is the e-learning method. E-learning is an internet-based learning method. By integrating an internet connection, it is hoped that learning activities can facilitate interaction between teachers and students even though they do not meet face-to-face as found in a classroom setting. A learning system by integrating an internet connection with the teaching and learning process is known as an online learning system or virtual learning system [6].

Several problems usually arise in online learning, namely the use of teaching materials, student interaction, and learning atmosphere [4], [7]. Teaching materials have a very important role in the learning process as a source of study in learning [8]. Student interaction is one of the factors to help students achieve more optimal learning outcomes. The learning environment is just as important as teaching materials and student interaction in helping students achieve better learning outcomes. In line with their research, [9] claimed that in implementing distance learning, several dimensions must be the main concern. These dimensions include Material or teaching mode, student interaction, and learning atmosphere. Therefore, this study focuses on students' perceptions of the implementation of online learning.

To develop blended Learning concept, Carmen [10] stated that there are five ways to develop blended learning, namely: (1) live-event, namely direct or face-to-face learning; (2) self-paced Learning, combining conventional learning with self-paced learning that allows learners to learn whenever and wherever by using various learning materials, both text-based and multimedia-based in encouraging students to learn independently; (3) collaboration between teacher and students; (4) assessment, a way to measure learning success (assessment technique). In Blended Learning, construction must mix a combination of types of assessments, both test and non-test, or tests that are more authentic (authentic assessment/portfolio) in the form of 
projects, products and many more. In addition, online and offline assessment forms need to be considered to provide convenience and flexibility for learning participants to take part in or carry out the assessment; and (5) materials support. The most important thing to be noted that the integration between face-to-face learning and online learning is the availability of the materials. Learning materials should be designed in digital form and could be accessed by learning students offline or online.

The learning system is implemented through a personal computer (PC) or laptop connected to an internet network connection. Teachers can do learning together at the same time using groups on social media, such as WhatsApp (WA), Telegram, Instagram, Google classroom, Zoom application, Moodle, Google Meet or other learning media [11]. Thus, the teacher can ensure that students take part in learning, even though done in different places. Thus, online learning using the blended learning method as an effective solution in learning from home to break the chain of the spread of Covid-19, physical distancing (maintaining a safe distance) is also a consideration for choosing this learning. Good collaboration between teachers, students, parents, and the school/madrasah determines more effective online learning.

\section{Research Methods}

This study is a survey research with the number of samples of this research were forty-two elementary school students and forty-two elementary school teachers in Manggarai regency using a random sample technique based on filling out a questionnaire using Google forms. The instrument used was a questionnaire with a Likert scale to collect data on student and teacher perceptions of the implementation of mathematics learning during the Covid-19 pandemic, which was carried out in a blended manner. Categories include strongly agree, agree, neutral, disagree, and strongly disagree [12], [13].

The instrument statement items consist of 25 items consisting of three components: the dimensions of teaching materials, the dimensions of the atmosphere or learning environment, and the dimensions of student interaction. Based on the instrument validity test results, it was found that both the student's perception instrument and the teacher's perception were all declared valid, with the reliability coefficients being 0.84 and 0.81 in the high category, respectively. Respondents' answers about teachers' perceptions of the dimensions of teaching materials have a mean of 3.15; the dimension of the learning atmosphere means 2.89 , and the dimension of student interaction is 2.78 .

Meanwhile, based on respondents' answers, students' perceptions of the dimensions of teaching materials have a mean of 3.56; dimension of learning atmosphere 2.45; and the dimension of student interaction is 3.05. The data analysis technique used quantitative descriptive techniques by analysing respondents' answers to the instrument items on three dimensions.

\section{Results and Discussion}

Based on the results of data analysis, respondents' answers about the teacher's perception of the dimensions of teaching materials have a mean of 3.15; the dimension of the learning atmosphere means 2.89; and the dimension of interaction is 2.78. Meanwhile, based on 
respondents' answers, students' perceptions of the dimensions of teaching materials have a mean of 3.56; dimension of learning atmosphere 2.45; and the dimension of student interaction is 3.05.

Table1. Teacher's and Students' Perceptions Categories

\begin{tabular}{|c|c|c|c|}
\hline Dimensions & & Teacher's & Students' \\
\hline \multirow{9}{*}{$\begin{array}{l}\text { Teaching } \\
\text { Materials }\end{array}$} & I am happy with the online learning model. & 3.15 & 3.56 \\
\hline & I am happy to be able to submit math material online. & & \\
\hline & $\begin{array}{l}\text { I am not happy with the blended learning model for } \\
\text { math material with assignments. }\end{array}$ & & \\
\hline & $\begin{array}{l}\text { This blended learning deserves appreciation and } \\
\text { attention among students. }\end{array}$ & & \\
\hline & $\begin{array}{l}\text { I am happy with the online grading system for grading } \\
\text { math subjects. }\end{array}$ & & \\
\hline & I like to use certain platforms for learning math. & & \\
\hline & $\begin{array}{l}\text { I am happy when delivering learning materials, giving } \\
\text { assignments, attending attendance lists, and making } \\
\text { online assessments. }\end{array}$ & & \\
\hline & $\begin{array}{l}\text { Online learning directs students to be able to learn } \\
\text { independently and creatively. }\end{array}$ & & \\
\hline & $\begin{array}{l}\text { For the difficult learning material, I do it face-to-face } \\
\text { meeting. }\end{array}$ & & \\
\hline \multirow{7}{*}{$\begin{array}{l}\text { Learning } \\
\text { Atmosphere }\end{array}$} & Online learning is better than classroom learning. & 2.89 & 2.45 \\
\hline & Face-to-face learning is better than online learning. & & \\
\hline & $\begin{array}{l}\text { Online learning is very difficult to determine the } \\
\text { level of cognitive development and student learning } \\
\text { progress. }\end{array}$ & & \\
\hline & $\begin{array}{l}\text { Face-to-face learning is better for measuring } \\
\text { students' affective dimensions. }\end{array}$ & & \\
\hline & $\begin{array}{l}\text { Face-to-face learning is better for measuring } \\
\text { students' psychomotor dimensions. }\end{array}$ & & \\
\hline & $\begin{array}{l}\text { I am having trouble using certain platforms for online } \\
\text { learning. }\end{array}$ & & \\
\hline & $\begin{array}{l}\text { I have an internet access problem for my online } \\
\text { learning class. }\end{array}$ & & \\
\hline
\end{tabular}


Student Interaction

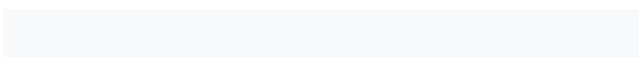

I always respond to student inquiries online.

I don't like online discussions with a classmate.

Online learning helps me develop skills and knowledge

of information and communication technology.

I can gain broad benefits and knowledge with online-

based learning models.

I like to submit assignments online.

I like sending assignments offline.

Online learning has the potential to broaden my insights in terms of reading knowledge.
\end{abstract}

2.78

3.05

I like to send assignments directly to the teacher's house.

Based on the results of data processing carried out, in general, students have a positive tendency towards implementing online learning. This can be seen from the findings that have been discussed. Students can adapt and adjust to all the dimensions contained in the online learning process. Although statistically, it can be seen that the tendency of students to respond that learning activities from school is better than learning online from home. According to the researchers, these two activities (online and offline) are needed by students in growing cognitive and meta-cognitive aspects.

By studying at school, students can interact and socialize with their friends, which can foster a spirit of solidarity and brotherhood; however, on the other hand, students who are technologysavvy and familiar with information technology-based literacy can foster a spirit and numeracy activities cannot be avoided. The combination of these learning platforms will make students have holistic abilities in learning. The learning environment plays a very important role in the learning process to create a comfortable atmosphere and motivate students in learning to achieve better learning outcomes. The learning environment is an important part of helping students have a high learning spirit. Therefore the learning environment must create a good atmosphere and motivate in teaching and learning activities [7].

Likewise, research conducted by [14] shows that the implementation of e-learning-based at SMK Negeri 4 Jakarta has not gone well as seen by the internet network, which is sometimes unstable and disconnected, and there are still some teachers and students do not understand about information communication technology. The obstacles faced are that most students who followed in online learning did not have enough internet quota, residential locations, which did not have internet access, and non-android-based phones.

To overcome internet quota barriers, [15] in his research showed that the most effective way to reduce quotas is to prepare and provide low-quota applications as done by UIN Sunan Gunung Djati Bandung in providing E-Knows applications that do not require a large quota to access them. In addition, there are services in the form of free quotas of tens of GigaBytes (GB) in collaboration with providers to access education services.

The solution that can be used as a reference in responding to various obstacles to increase learning from home is by realizing meaningful education that focuses not only on achieving 
academic and cognitive aspects. One way is to follow the directions in the Circular Letter of the Minister of Education and Culture No. 4 of 2020 concerning the Implementation of Policies in the Emergency Period for the Spread of Coronavirus Disease (Covid-19).

Point 2 of the circular explains that the learning process from home is carried out with the following provisions: First, it is carried out to provide a meaningful learning experience for students without being burdened with the demands of completing all curriculum achievements for grade promotion and graduation. Second, it focuses on life skills education, including the Covid-19 pandemic. Third, learning activities and assignments may vary between students, according to their interests and conditions, including the gap in access/learning facilities at home. Fourth, evidence or products of learning activities from home are given qualitative and useful feedback from the teacher without being required to give scores/values quantitatively.

As a form of continuous improvement of the quality of online education, several things must be pursued, including, First, educational institutions must begin to improve facilities and infrastructure to support online learning such as infrastructure, Learning Management System (LMS), and an adequate repository. Second, increasing the capacity of educators who support the implementation of online learning. Third, the expansion of technology platform support for learning activities is expected to continue after the Covid-19 emergency period has ended. Various efforts and increased insight related to the implementation of online learning must be sustainable to face the increasingly rapid flow of information and communication technology as a requirement in growing Lifelong Learning Capacity (LLC) activities. In addition, the formation of a rabbinic generation in achieving civil society life becomes a bulwark in dispelling the currents of globalization and westernization so that the Indonesian nation will have a strong and useful generation [9].

Based on the results of this study, it can be concluded that the implementation of blended mathematics learning for students in the Manggarai regency has not been running well. This occurs due to not all students have android phones or laptops; weak internet connection, there are even many student domicile areas that do not have an internet network, limited internet quota, teachers are not used to controlling student attendance in online learning or using google forms applications, teachers are not accustomed to giving assessments using certain applications, both teachers and students have not accustomed to using virtual face-to-face learning using video conferencing which hinders the learning process during the covid-19 pandemic.

\section{Conclusion}

The process of learning from home through online learning, which is a manifestation of distance education programs, although it cannot be claimed to be ideal, has had a relevant impact on the importance of mastering and using information communication technology in education. However, it is realized that the challenges of online learning are more technical, such as those related to teaching materials, environmental conditions and interactions in the learning process.

Nevertheless, on the other hand, cultivating meaningful learning becomes an urgent issue to be fulfilled. Fulfilling all aspects that can support and form ideal students is certainly a must and an obligation for all of us in facing the increasingly strong flow of information and communication information technology development. All of this will lead to the formation of a 
long-life learning capacity, namely future generations who have literacy and numeracy skills and have the awareness to become a strong character generation and adapt to digital technology.

\section{References}

[1] Kemdikbud, "Surat Edaran Kemdikbud RI No. 4 Tahun 2020 Tentang Pelaksanaan Kebijakan dalam Masa Darurat Penyebaran Covid-19," pp. 1-3, 2020.

[2] T. Dewayani, "Flexible Working Space (FWS) Sebagai New Normal Kementerian Keuangan Pasca Pandemi Covid-19," DJKN-Kemenkeu, 2020, [Online]. Available: https://www.djkn.kemenkeu.go.id/kanwil-jabar/baca-artikel/13122/Flexible-Working-Space-FWSSebagai-New-Normal-Kementerian-Keuangan-Pasca-Pandemi-Covid-19.html.

[3] J. L. Moore, C. Dickson-Deane, and K. Galyen, "E-Learning, online learning, and distance learning environments: Are they the same?," Internet High. Educ., vol. 14, no. 2, pp. 129-135, 2011, doi: 10.1016/j.iheduc.2010.10.001.

[4] M. F. Fortune, M. Spielman, and D. T. Pangelinan, "Students' Perceptions of Online or Face-to-Face Learning and Social Media in Hospitality, Recreation and Tourism," MERLOT J. Online Learn. Teach., vol. 7, no. 1, pp. 1-16, 2011.

[5] S. Menggo, H. Midun, and P. Pandor, "Students' Digital Literacy Competence and English Study Habits," 2021, doi: 10.4108/eai.3-6-2021.2310655.

[6] Y. Bentley, H. Selassie, and A. Shegunshi, "Design and evaluation of student-focused eLearning," Electron. J. e-Learning, vol. 10, no. 1, pp. 1-12, 2012.

[7] M. Radovan and D. Makovec, "Adult learners' learning environment perceptions and satisfaction in formal education-case study of four East-European countries," Int. Educ. Stud., vol. 8, no. 2, pp. $101-$ 112, 2015, doi: 10.5539/ies.v8n2p101.

[8] S. Menggo, I. M. Suastra, M. Budiarsa, and N. N. Padmadewi, "Needs analysis of academic-English speaking material in promoting 21 st century skills," Int. J. Instr., vol. 12, no. 2, pp. 739-754, 2019, doi: 10.29333/iji.2019.12247a.

[9] S. Zuriati and B. Briando, "Webinar Dan Call for Papers 'Menyongsong Era Merdeka Belajar ' 2020," Menyongsong Era Merdeka Belajar, no. June, pp. 1-14, 2020.

[10] S. F. Tsaniyah, H. D. Ayu, and H. Y. Pratiwi, "Pengaruh Model Blended Learning menggunakan Schoology Terhadap Prestasi Belajar ditinjau Dari Kemandirian Belajar Siswa,” J. Terap. Sains Teknol., vol. 1, no. 1, pp. 71-77, 2019, [Online]. Available: http://ejournal.unikama.ac.id/index.php/jtst/article/view/3236.

[11] S. Menggo, I. M. Suastra, and N. N. Padmadewi, "Self-recording videos to improve academic English-speaking competence," Asian EFL J., vol. 25, no. 5.2, pp. 133-152, 2019.

[12] J. W. Creswell, . United States of America: SAGE Publication., 2014.

[13] H. N. Boon and D. A. Boon, "Analyzing Likert Data," J. Ext., vol. 50, no. 2, 2012, [Online]. Available: http://www.joe.org/joe/2012april/tt2p.shtml[8/20/2012 9:07:48 AM].

[14] G. K. Permana and D. Daryati, "Persepsi Siswa dan Guru Terhadap Pelaksanaan Pembelajaran Berbasis E-Learning Di SMK Negeri 4 Jakarta,” J. PenSil, vol. 2, no. 2, pp. 111-117, 2013, doi: 10.21009/jpensil.v2i2.9872.

[15] D. dkk Jamaludin, "Pembelajaran Daring Masa Pandemik Covid-19 Pada Calon Guru :," Karya Tulis Ilm., p. 2, 2020, [Online]. Available: http://digilib.uinsgd.ac.id/30518/. 